\title{
CARING FOR OUR PATIENTS
}

\author{
B.N. HUNT
}

\section{OPSOMMING}

Elkeen weet wat die gehalte van versorging wat die verpleegkundige aan haar pasiënte gee behoort te wees. Word hierdie behoort te wees egter so oorgedra na die werklike situasie?

Dié vraag word objektief beskou aan die hand van navorsing oor pasiënt-tevredenheid, voorligting oor borsvoeding, die sterwende pasiënt en drukplekversorging.

Die verpleegkundige moet haar pasiënt nie net met haar gevoel en hande versorg nie, maar ook deur haar denke en kennis.

\section{ARE WE CARING?}

Discussions about the quality of caring given by nurses to patients, tend to become overlaid with emotion - older nurses accuse younger nurses of giving less meticulous care today than that was given twenty or maybe forty years ago. We all get very excited about the whole question of care, probably because care for people is basic to the philosophy of all nursing and any suggestion that care is less than good, or of doubtful quality, is deeply resented and threatening to nurses of any age.

Emotion makes for clouded judgment. The blanket term care is hard to define and it is useful to look at the concept of care in relation to patients and nursing rather more objectively.

Susan Hinchliff ${ }^{(1)}$ discusses the nature of nursing and finds the well-used definition of nursing as $a$ caring art based on individual needs useful. She then considers nursing as a system of skills which are of two main types - caring and technical.

Can we measure the effectiveness of these skills? We are all quite familiar with what ought to be; nurses are never slow to discuss how any given aspect of nursing care ought to be accomplished.

It is rewarding and salutary to look at how ought to be is translated into what is and here one has to look at what is actually happening between the individual nurse and the individual patient. It is this approach that the Department of Nursing at the University of Natal has tried to foster. One reason which is unfailingly given to justify the establishment of nursing degrees is, of course, the vital necessity for educating nurses in research and its techniques to enable them to look objectively at the practice of nursing. Clearly, research is not an end in itself but is a means towards the delivery of expert and informed nursing care.

\section{PATIENT SATISFACTION}

Firstly, the patients themselves can be asked how they feel about the caring art of nursing. After a spell as a patient in a large general hospital in Natal, how do they rate their satisfaction with the quality of care they received? Simple questionnaires given to all in-patients over the period of one month showed only one adverse comment about the nursing. The food, the noise, the air temperature all came under fire, but the nurses were rated as splendid. Nursing staff were pleasantly gratified.

But studies in Britain into the level of patient satisfaction with nursing care in Britain have over the years shown very much the same result. Patients, vulnerable by definition, are grateful for care received while they are in a hospital and patients (unless they are nurses) are in no position to discriminate between good and poor nursing as nurses would define it. The patient can, of course, tell the difference between good and bad manners and it is suspected that this is what the response to the abovementioned research reflects in regard to nursing.

\section{CHILD-FEEDING PRACTICES}

What about the technical aspects of nursing? Some studies conducted by staff and students over the last two or three years shed interesting light on this question. In 1978 a survey investigating child feeding practices among Coloured and White mothers in Durban was carried out in conjunction with the Department of Obstetrics at the Medical School. 227 Coloured mothers and 121 White mothers - which was quite a big sample - were interviewed.

Midwives, of course, are under an obligation to encourage breastfeeding but seldom have an opportunity to see if their encouragement pays dividends. $80 \%$ of the White and $91 \%$ of the Coloured mothers interviewed had at least attempted breast-feeding. However, only $38 \%$ of White babies who were under three months old as compared with $83 \%$ of Coloured babies in this age group, were still being breast-fed.

What came as an unexpected and thought-provoking shock, was that $43 \%$ (29) of the primiparous White mothers, whom one would have imagined to be the focus of special help and encouragement in the ante-natal and immediate postpartum periods did not recall being given any advice about breast-feeding at all - not in the clinic, doctor's surgery or hospital. It was known that the midwives gave advice to these mothers but it seems it simply made no impression.

In contrast, only $11 \%$ (87) of primiparous Coloured mothers did not recall advice being given about breast-feeding. 
Even more cutting-down-to-size was the finding, on further analysis, that successful breast-feeding (defined as breast-feeding for at least three months) did not relate at all to whether breast-feeding guidance was remembered or not. One must conclude that the midwives who sincerely thought they were doing their caring job - and, in fact, cared about this very much - might as well have been reciting nursery rhymes instead of giving carefully considered advice about breastfeeding. Of course, we are not the first, or likely to be the last, group of midwives to ponder about methods for effective health education. (2)

Kortenbout ${ }^{(3)}$ in her study on how seventeen young mothers fed their babies found that the mother's own mother was the figure of overwhelming significance in regard to advice about child-rearing.

\section{THE DYING PATIENT}

During 1978 , a senior staff member of the Department of Nursing, University of Natal, was asked to give a talk to nurses on the care of the dying patient. Rather than simply reiterate the valuable work of Saunders ${ }^{(4)}$, Kublar-Ross ${ }^{(5)}$ and others, she thought it would be useful to investigate, within obvious limits, what in fact happens regarding the dying patient in hospital. To this end she sent out about a hundred questionnaires to the matrons of all hospitals and nursing homes in Natal and KwaZulu, asking for information about all deaths which occurred in their hospitals for the month of March 1978.

Response to this postal questionaire was much better than anyone had anticipated. There was a $75 \%$ return, giving detail about 1500 deaths, excluding neo-natal deaths or still-births.

Two findings from the analysis of these returns seem very important regarding the caring aspect of nursing. So many deaths were lonely. Most Black patients died with no relatives present. It is known that this is a particular fear among Blacks and it would seem to be well-founded. But this pattern was however, not markedly different from other groups. Indian patients are a very well-visited group but they mostly died alone, and in one White hospital, only $8 \%$ of those dying had their family with them.

The physical care of the dying patient seemed good in that few patients had complications of bed rest and most ward sisters felt that nothing more could have been done in order to make death more comfortable.

The second important point relates to community health nursing. $50 \%$ of the deaths were of Black children, mostly under the age of two years, suffering from preventable conditions. Could nurses do more about this? Certainly the element of caring applies here. ${ }^{(6)}$

\section{CARE OF PRESSURE PARTS}

Lastly, in order to illustrate technical aspects of nursing care, a pressure sore survey conducted among
499 White and Coloured hospitalised patients in Natal, showed that nurses were not effective in seeing that the correct mobility-aiding equipment was delivered to those patients most at risk of developing symptoms of pressure. Any first year student nurse can recite the causes of pressure sores, but the translation of knowledge into relevant action is wanting. Again, we are not the first nurses to have this disturbing fact brought home to us. ${ }^{(7,8)}$

\section{CARE WITH THOUGHT}

We say we care, and so we do. But are we caring with our feelings and our hands and feet, but not our heads? There is a need to stop, think, look, investigate, and to put into practice that which we know, but which somehow, in the hurlyburly of the working day, does not get translated into effective caring action.

\section{REFERENCES}

1. HINCHLIFF, S. Teaching Clinical Nursing. Churchill Li vingstone, London. 1979.

2. COLE. R.: HOLLANDS. S. Recall of Health Educa tion Display Materials. Hlth. Educ. J. Vol 39 No 3 p 74 . 79. 1980

3. KORTENBOUT, W.P., Problems Experienced by Primigravidae in Early Feeding of their Infants and the Implications for Health Personnel. Unpub. thesis. Univ. of Natal. 1979

4. SAUNDERS, C., Care of the Dying. Macmillan. London. 1959 .

5. KUBLER-ROSS, E. On Death and Dying. Tavistock Publications. London. 1970.

6. BROOKES, H.B. . Unpublished ralk given on The Dying Patient in Durban in April 1978 at a nursing symposium Numing Uniry for a Healthy Community.

7. BENDALL, E. So you Passed, Nurse. An exploration of some of the assumptions on which writren examinations are based. Royal College of Nursing. London. 1975.

8. HUNT, J.M., The Teaching and Procice of Surgical Dressings in Three Hospitals. Royal College of Nursing. London. 1974. 